\title{
The Impact of Climate on Outbound Tourism in Hong Kong: Resident's Mode of Transport
}

\author{
J. M. Luo ${ }^{1}$, C. F. Lam², Hanqin Qiu ${ }^{3} \&$ Daisy X. F. Fan ${ }^{3}$ \\ ${ }^{1}$ Faculty of International Tourism and Management, City University of Macau, Macau \\ ${ }^{2}$ Department of Finance, The Chinese University of Hong Kong, Hong Kong \\ ${ }^{3}$ School of Hotel and Tourism Management, The Hong Kong Polytechnic University, Hong Kong \\ Correspondence: C. F. Lam, Department of Finance, The Chinese University of Hong Kong, Room 1201, 12/F, \\ Cheng Yu Tung Building, No. 12 Chak Cheung Street, Shatin, N.T. Hong Kong. Tel: 1-852-3943-3734. E-mail: \\ b126097@mailserv.cuhk.edu.hk
}

Received: February 1, 2015

doi:10.5539/jms.v5n2p31
Accepted: February 25, $2015 \quad$ Online Published: May 31, 2015
URL: http://dx.doi.org/10.5539/jms.v5n2p31

\begin{abstract}
Hong Kong is one of the largest outbound tourist generators in the Asia-Pacific region; the increasing demand of traffic has resulted in a growing concern with various types of transport operators. In recent years, climate change has become a key issue debated at the international and national levels. Quarterly data from 2005 to 2013 is used in the study to find out the importance of the climate impact on Hong Kong resident departures and mode of transport. The result suggests that climate does not affect Hong Kong resident's mode of transport uniformly. Furthermore, this study suggests implications for policy makers and practitioners.
\end{abstract}

Keywords: resident departures, mode of transport, climate change, Hong Kong

\section{Introduction}

Tourism is a major sector of the Hong Kong economy. According to the UNWTO World Tourism Barometer (UNWTO, 2014), Hong Kong is the sixteenth largest tourist generating market in 2013. The number of Hong Kong resident departures increased from 61.1 million in 2001 to 84.4 million in 2013. Regarding to the mode of transport, in 2013, there are 8.6 million (10.2\%) Hong Kong residents traveled by air, 7.7 million (9.1\%) by sea and 68.1 million $(80.7 \%$ ) by land (HKTB, 2013). Hong Kong is one of the largest outbound tourist generators in the Asia-Pacific region and the dimension of safety is the top concern of Hong Kong residents when they choose travel destinations (Zhang, Qu, \& Tang, 2004). The steadily growing departures number in Hong Kong has drawn tremendous attention from local and international tour companies to understand Hong Kong residents' departures (See Table 1).

Table 1. Number of Hong Kong resident departures (2001-2013)

\begin{tabular}{lllll}
\hline \multirow{2}{*}{ Year } & Mode of Transport & & & \\
\cline { 2 - 5 } & Total & By Air & 7750167 & 48333706 \\
2001 & 61095895 & 5012022 & 7643297 & 51926258 \\
2002 & 64540132 & 4970577 & 6779382 & 49627148 \\
2003 & 60936082 & 4529552 & 7254453 & 56307578 \\
2004 & 68903433 & 5341402 & 7365666 & 59477783 \\
2005 & 72299897 & 5456448 & 7931970 & 62140675 \\
2006 & 75811781 & 5739136 & 8870013 & 65673824 \\
2007 & 80684674 & 6140837 & 8768330 & 66918641 \\
2008 & 81910703 & 6223732 & 8041246 & 67595508 \\
2009 & 81958282 & 6321528 & 8260078 & 69357996 \\
2010 & 84442451 & 6824377 & 8356745 & 69328973 \\
2011 & 84815917 & 7130199 & 7961725 & 69505403 \\
2012 & 85276018 & 7808890 & 7733601 & 68083539 \\
\hline
\end{tabular}

Sources: HKTB, 2001-2013. 
Hong Kong has a highly developed and sophisticated transport network, encompassing both public and private transport. Getting around Hong Kong is easy using various modes of transport, including the MTR, bus, ferry and taxi. Hong Kong has an efficient and reliable public transport system to facilitate the movement of passengers within the territory. The system on average was carried over 11 million passengers daily in 2009 (Census and Statistics Department of Hong Kong, 2010). Hong Kong residents would leave Hong Kong by Air, Sea and Land. The immigration control points by Air there are Airport, by Sea there are China Ferry Terminal, Macau Ferry Terminal, Harbour Control and River Trade Terminal, by Land there are Hung Hom Station, Lok Ma Chau Control Point, Lo Wu Control Point, Man Kam To Control Point and Sha Tau Kok Control Point (See Figure 1).

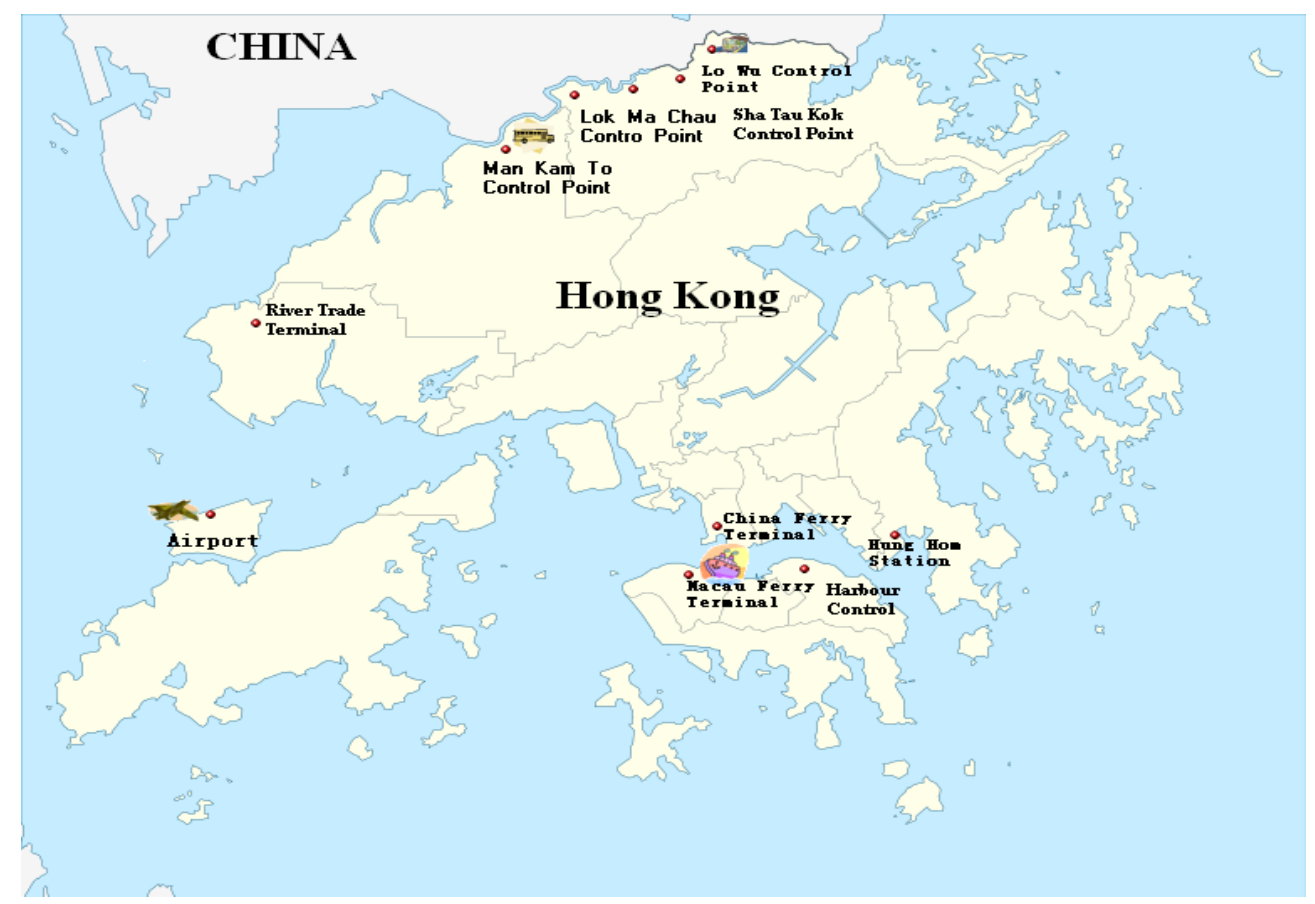

Figure 1. Map of Control Points in Hong Kong

Source: HKTB, 2013.

The capacity of domestic market, especially inbound tourism, depends largely on climate. Visitors generally prefer destination to have favorable weather conditions. Changes in climatic conditions such as variations in temperature, rainfall, humidity, fog-induced visibility, tropical cyclones, thunderstorms, and solar radiation have an impact on the tourism sector. In recent years, Hong Kong's mean weather conditions in different seasons have been changing. This may be caused by greenhouse gases atmospheric concentration and local urbanization, which is also known as "urban heat islands", where temperatures are higher than in their rural surroundings. Urban heat island can be caused by several factors such as concrete and tarmac replacing vegetation, the presence of building reducing air ventilation, anthropogenic heat production and motor vehicle emissions (Climate Change Business Forum, 2013). The average increase of temperature increased from $0.12^{\circ} \mathrm{C}$ per decade during the post war period (1883-2012) to $0.22^{\circ} \mathrm{C}$ per decade during the 1983-2012 (see Figure 2) (Hong Kong Observatory, 2013). 


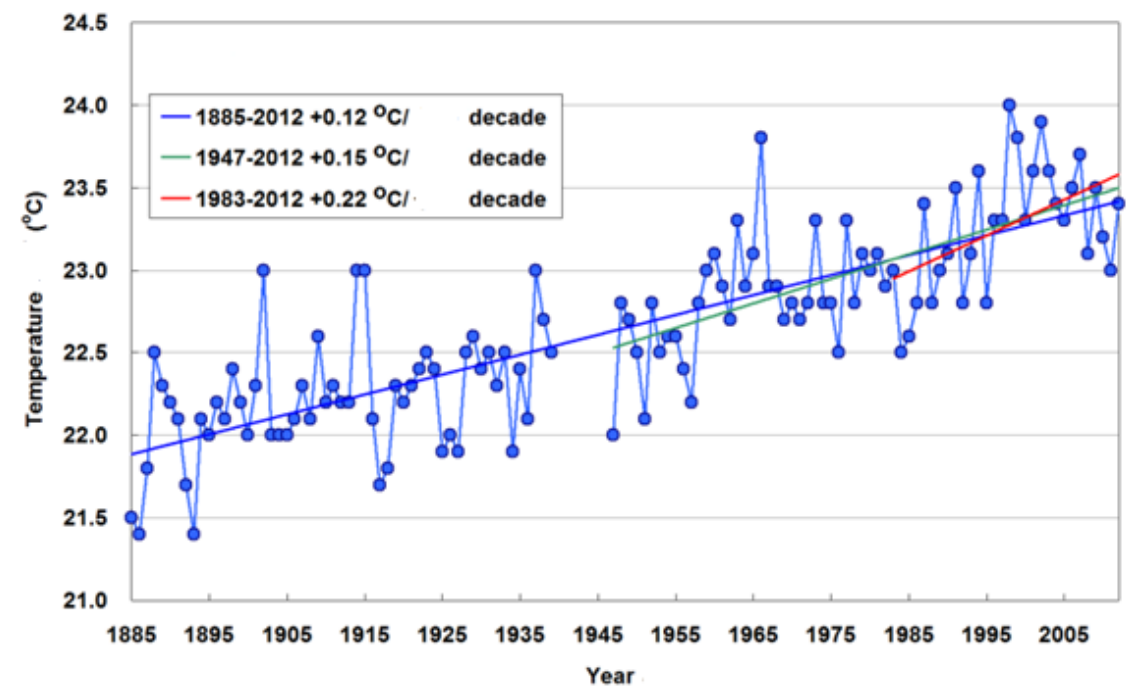

Figure 2. Annual mean temperatures recorded at the Hong Kong Observatory Headquarters (1885-2012). Data are not available from 1940 to 1946

Sources: adopted from Hong Kong Observatory, 2013.

Climate change is now recognized by the majority of governments and scientists throughout the world as a significant social and environmental issue facing the global population and its resources (Amelung, Nicholls, \& Viner, 2007). The Hong Kong Observatory Climate Forecasting Report (Leung, Wu, \& Yeung, 2006) predicted that in the following decade, the number of very hot days (those with a maximum temperature of $33^{\circ} \mathrm{C}$ or above) experienced each summer would roughly double. This represents an increase from 11 days to 24 days. The number of hot nights will increase to 30 nights per year, which is 4 times the current record. The number of cold days in winter will reduce to less than 1 day annually, from the current 21 days. Oscillation between wet and dry will be more pronounced; and wet weather will be more frequent because the increase of rainfall and the increase likelihood of storms. Thus, the change in mean weather conditions in different seasons could alter the pattern of seasonal variation in quarterly international tourism arrivals in Hong Kong, which could have an impact on employment, planning, and investment in the tourism sector.

No previous attempt has been made to identify the link between Hong Kong resident departures and climate variables such as temperature, humidity level, visibility, and wind. This study represents an exploratory study to understand the relationship between climate and the mode of transport. In recent years, climate change has become a key issue debated at the international and national levels. However, climate change's information has in the past been neglected in the strategic planning process for Hong Kong's tourism industry. This study provides an accurate and necessary dataset on climate change that enables policy makers to make more informed decisions on tourism marketing, planning, and investment. Furthermore, this information should be a vital resource for the tourism industry and will allow it to make the appropriate industry supply response in light of changing Hong Kong resident departures and mode of transport due to climate change.

\section{Tourism and Climate}

Weather is a mix of daily atmospheric events including temperature, rainfall, and humidity, whereas climate is weather pattern on average in a certain place over a long period of time. The drawback of previous studies which includes climate in demand of tourism models is that in emphasizing the impact of climate variation on at the international and national levels. Few studies, particularly quantitative studies, have discussed the impact of climate in outbound tourism demand (Eugenio-Martin \& Campos-Soria, 2010; Lise \& Tol, 2002). In Canada, Wilton and Wirjanto (1998) estimated that a $1{ }^{\circ} \mathrm{C}$ above normal summer temperature increases domestic tourism expenditures by approximately $4 \%$. Lise and Toll (2002) discuss the reasons for optimal destination temperature estimation. When there is a deviation of temperature from the optimal, there will be impact on tourism demand. In another study, Goh, Law and Mok (2008) measure the impact of leisure time and climate on annual Hong Kong inbound tourism demand, by using both the rough set algorithm approach and econometric analysis consisting of both quantitative economic factors and qualitative non-economic factors. Focusing on the long haul US and UK demand for Hong Kong tourism, this study showed that leisure time and climate have stronger 
impacts on tourist arrivals than do economic factors. Taylor and Ortiz (2009) used UK regional tourist and climate data to estimate the impact of temperature, precipitation, and sunny conditions on domestic tourism by using panel data statistics. They found that these climate variables have a significant impact on domestic tourism. A similar study is conducted by Eugenio-Martin and Campos-Soria (2010). They studied the socioeconomic characteristics of the households in Europe. The results showed that residents in regions with better climate indices have a higher probability of travelling domestically and a lower probability of travelling abroad.

A further problem of using the climate variables is the choice of variables to define climate. Mieczkowski (1985) constructed a Tourism Climate Index (TCI) using the following sub-indices: a daytime comfort index (CID), a daily comfort index (CIA), precipitation (R) (mm), sunshine (S) and wind speed (W) $(\mathrm{m} / \mathrm{s}$ or $\mathrm{KM} / \mathrm{h})$. The daytime comfort index (CID) is measured by the maximum daily temperature and minimum daily relative humidity. The daily comfort index (CIA) is measured by average daily temperature and average daily relative humidity. Sunshine is measured by the number of sunshine in a day. The TCI is computed using the following formula: $\mathrm{TCI}=4 \mathrm{CID}+\mathrm{CIA}+2 \mathrm{R}+2 \mathrm{~S}+\mathrm{W}$. The highest weight is placed to CID while precipitation and sunshine have the second largest weight. Wind has the lowest weight. Goh et al. (2008) and Goh (2012) applied the TCI index to Hong Kong data. They constructed a climate index for Hong Kong, including following climate variables: a daytime comfort index comprising maximum daily temperature and minimum daily relative humidity; a daily comfort index composed of daily temperature and daily relative humidity; and ratings for precipitation in Hong Kong, duration of sunshine, and wind speed.

Although constructing a climate index has its advantages, it also has some drawbacks. Amelung et al. (2007) claimed that TCIs apply only to sightseeing, shopping and general forms of tourism activities. Alternatively, TCIs are not applicable to climate-dependent activities, such as winter sports. Different climatic variables should be used for different climate-dependent tourism activities and different locations. A more disaggregated approach should be employed to overcome the problems commonly associated with currently climate change indexes which are used as a determinant of tourism demand. This would involve estimating the impact of individual climatic variables on tourism flow (Mieczkowski, 1985). Economic related variables such as income, price, and transport cost, etc. will be also included in the study.

\section{Method}

The study is based on secondary data collected by the Hong Kong Tourism Board, Census and Statistics Department of Hong Kong, Hong Kong Observatory and U.S. Energy Information Administration. Quarterly data from 2005 to 2013 was used in the study to find out the importance of the climate impact on Hong Kong resident departures and mode of transport. One specific question of interest in this study is to understand how climate affects Hong Kong resident departures and mode of transport. The following general model was developed:

$$
\begin{aligned}
& \text { 1. } \operatorname{HKRD}_{\mathrm{t}}=f\left(\mathrm{GDP}_{\mathrm{t}}, \operatorname{CPI}_{\mathrm{t}}, \operatorname{Cost}_{\mathrm{t}}, \operatorname{Temp}_{\mathrm{t}}, \operatorname{Hum}_{\mathrm{t}}, \operatorname{Sun}_{\mathrm{t}}, \operatorname{Wind}_{\mathrm{t}}\right) \\
& \text { 2. } \operatorname{HKAD}_{\mathrm{t}}=f\left(\mathrm{GDP}_{\mathrm{t}}, \operatorname{CPI}_{\mathrm{t}}, \operatorname{Cost}_{\mathrm{t}}, \operatorname{Temp}_{\mathrm{t}}, \operatorname{Hum}_{\mathrm{t}}, \operatorname{Sun}_{\mathrm{t}}, \operatorname{Wind}_{\mathrm{t}}\right) \\
& \text { 3. } \operatorname{HKSD}_{\mathrm{t}}=f\left(\mathrm{GDP}_{\mathrm{t}}, \mathrm{CPI}_{\mathrm{t}}, \operatorname{Cost}_{\mathrm{t}}, \operatorname{Temp}_{\mathrm{t}}, \operatorname{Hum}_{\mathrm{t}}, \operatorname{Sun}_{\mathrm{t}}, \operatorname{Wind}_{\mathrm{t}}\right) \\
& \text { 4. } \operatorname{HKLD}_{\mathrm{t}}=f\left(\mathrm{GDP}_{\mathrm{t}}, \operatorname{CPI}_{\mathrm{t}}, \operatorname{Cost}_{\mathrm{t}}, \operatorname{Temp}_{\mathrm{t}}, \operatorname{Hum}_{\mathrm{t}}, \operatorname{Sun}_{\mathrm{t}}, \operatorname{Wind}_{\mathrm{t}}\right)
\end{aligned}
$$

Where

$\mathrm{HKRD}_{\mathrm{t}}=$ Hong Kong resident departures number at time $\mathrm{t}$, ln transformed;

$\mathrm{HKAD}_{\mathrm{t}}=$ Hong Kong resident departures number by Air at time $\mathrm{t}, \ln$ transformed;

$\mathrm{HKSD}_{\mathrm{t}}=$ Hong Kong resident departures number by Sea at time $\mathrm{t}$, $\ln$ transformed;

$\mathrm{HKLD}_{\mathrm{t}}=$ Hong Kong resident departures number by Land at time $\mathrm{t}$, ln transformed;

$\mathrm{GDP}_{\mathrm{t}}=$ Gross Domestic Product in Hong Kong at time t, ln transformed; (1USD=7.75 HKD)

$\mathrm{CPI}_{\mathrm{t}}=$ Consumer Price Index in Hong Kong at time $t$, In transformed;

Cost $_{\mathrm{t}}=$ Transportation costs in Hong Kong at time $\mathrm{t}$ measured in real oil price, ln transformed;

$\mathrm{Temp}_{\mathrm{t}}=$ Rating for daily temperature in Hong Kong at time $\mathrm{t}$ in degrees Celsius, $\ln$ transformed;

$\mathrm{Hum}_{\mathrm{t}}=$ Rating for daily humidity in Hong Kong at time $\mathrm{t}$ stated as a percentage, ln transformed

$\operatorname{Sun}_{t}=$ Rating for duration of sunshine in Hong Kong at time $t$ measured in hours per day, $\ln$ transformed;

Wind $_{t}=$ Rating for wind speed measured in kilometers per hour in Hong Kong at time $t$, ln transformed. 


\section{Variables}

\section{Dependent variables}

In the above models, HKRD, HKAD, HKSD and HKLD served as the dependent variables. The number of resident departures (HKRD) is divided into three categories which are the Honk Kong resident departures by Air (HKAD), Hong Kong resident departures by Sea (HKSD) and Hong Kong resident departures by Land (HKLD). This means HKRD $=$ HKAD+HKSD+HKLD.

\section{Independent variables}

Gross Domestics Product (GDP) is an alternative measure of income. This variable is measured in Hong Kong dollars. Scholars have been studying tourism demand by applying various and statistical models to understand tourism decisions and behaviors, Lyons, Mayor and Tol (2009) investigated GDP has positively influence choice probabilities on destination. Similarly, Chen (2010) found out GDP is slightly more crucial than an industry factor the hotel industry.

Consumer Price Index (CPI) is used as a proxy variable for tourism prices (Witt and Witt, 1995; Cheung and Law, 2001; Ching-chi and Si, 2010). Morley (1994) found that series correlate very highly with the destination CPI.

Transportation cost (Cost) is measured by the real oil price as a proxy variable for the cost of transportation in USD per barrel. Harvey (1986) found that the travel cost is significant explanatory variable in the airport access mode choice.

The climate variables are measured by temperature, humidity, duration of sunshine and wind speed. The average temperature is measured in degrees Celsius; Humidity is measured in percentage; Duration of sunshine is measured in hours per day; Wind speed is measured in kilometers per hour (Lise and Tol, 2002; Goh et al., 2008; Goh, 2012).

\section{Data Analysis and Results}

Table 2, Table 3, Table 4 and 5 report the descriptive statistics for all the variables included in the study. Table 2 presents the possible impacts of climate on Hong Kong resident departures, Table 3 presents the possible impacts of climate on Hong Kong resident departures by air, Table 4 presents the possible impacts of climate on Hong Kong resident departures by sea and Table 5 presents the possible impacts of climate on Hong Kong resident departures by land. Data are collected quarterly based from 01 January 2005 to 31 December 2013. This produces 36 data points in Hong Kong. The average number of Hong Kong resident departures (HKRD) established each year during the observation period is around 20.322 million; the average number of Hong Kong resident departures by air (HKAD) established each year during the observation period is around 1.673 million; the average number of Hong Kong resident departures by sea (HKSD) established each year during the observation period is around 2.036 million; and the average number of Hong Kong resident departures by land (HKLD) established each year during the observation period is around 16.613 million. The average of Gross Domestics Product (GDP) is 439392.28 HKD and the average value of Consumer Price Index (CPI) is around $100.46 \%$. The average number for Transportation cost (Cost) is around 80.26 USD per Barrel. Related to the climate variables, the average number of temperature (Temp) is 23.29 degrees Celsius, the average amount of humidity (Hum) is $77.85 \%$, the average number of duration of sunshine (Sun) is 5.08 hours per day and the average number of wind speed (Wind) is 22.79 kilometres per hour. The number of Hong Kong resident departures is significant and positively correlated with the independent variables, including Gross Domestics Product (GDP), Consumer Price Index (CPI), Transportation cost (Cost) and duration of sunshine (Sun) (See Table 2, 3, 4, 5). 
Table 2. Descriptive statistics and correlations in Hong Kong resident departures

\begin{tabular}{|c|c|c|c|c|c|c|c|c|c|c|c|}
\hline Variables & Mean & Std. Deviation & $\mathrm{N}$ & 1 & 2 & 3 & 4 & 5 & 6 & 7 & 8 \\
\hline 1.HKRD (No.) & 20322590.86 & 1229013.93 & 36 & & $.806^{* *}$ & $.723 * *$ & $.602 * *$ & 0.258 & -0.246 & $.410^{*}$ & -0.013 \\
\hline 2. GDP (million & 439392.28 & 63381.15 & 36 & & & $.916 * *$ & $.653 * *$ & 0.048 & $-0.400 *$ & $.352 *$ & .276 \\
\hline \multicolumn{12}{|l|}{ HKD) } \\
\hline 3. CPI $(\%)$ & 100.46 & 8.19 & 36 & & & & $.644^{*}$ & -0.035 & -0.201 & 0.064 & .160 \\
\hline 4. Cost (USD/Barrel) & 80.26 & 19.61 & 36 & & & & & 0.109 & -0.042 & 0.078 & -.078 \\
\hline 5. Temp $\left({ }^{\circ} \mathrm{C}\right)$ & 23.29 & 4.26 & 36 & & & & & & $.462 * *$ & $.447 * *$ & $-.576 * *$ \\
\hline 6. Hum (\%) & 77.85 & 5.19 & 36 & & & & & & & $-.485 * *$ & $-.688 * *$ \\
\hline 7. Sun (H/D) & 5.08 & 1.29 & 36 & & & & & & & & 0.024 \\
\hline 8. Wind $(\mathrm{K} / \mathrm{H})$ & 22.79 & 2.82 & 36 & & & & & & & & \\
\hline
\end{tabular}

**. Correlation is significant at the 0.01 level (2-tailed).

*. Correlation is significant at the 0.05 level (2-tailed).

Note. HKRD is Hong Kong resident departures number; GDP is Gross Domestic Product in Hong Kong; CPI is Consumer Price Index in Hong Kong; Cost is transportation costs in Hong Kong; Temp is rating for daily temperature in Hong Kong; Hum is rating for daily humidity in Hong Kong; Sun is Rating for duration of sunshine in Hong Kong; Wind is rating for wind speed measured in kilometers per hour in Hong Kong.

Table 3. Descriptive statistics and correlations in hong kong resident departures by air

\begin{tabular}{llllllllllll}
\hline Variables & Mean & Std. Deviation & $\mathrm{N}$ & 1 & 2 & 3 & 4 & 5 & 6 & 7 & 8 \\
\hline 1.HKAD (No.) & 1673376.33 & 263865.39 & 36 & $.883^{* *}$ & $.893^{* *}$ & $.627^{* *}$ & 0.283 & -0.027 & 0.271 & -0.094 \\
2. GDP (million HKD) & 439392.28 & 63381.15 & 36 & & $.916^{* *}$ & $.653^{* *}$ & 0.048 & $-0.400^{*}$ & $.352^{*}$ & .276 \\
3. CPI (\%) & 100.46 & 8.19 & 36 & & & $.644^{*}$ & -0.035 & -0.201 & 0.064 & .160 \\
4. Cost (USD/Barrel) & 80.26 & 19.61 & 36 & & & & 0.109 & -0.042 & 0.078 & -.078 \\
5. Temp ( $\left.{ }^{\circ} \mathrm{C}\right)$ & 23.29 & 4.26 & 36 & & & & & $.462^{* *}$ & $.447^{* *}$ & $-.576^{* *}$ \\
6. Hum (\%) & 77.85 & 5.19 & 36 & & & & & & & $-.485^{* *}$ & $-.688^{* *}$ \\
7. Sun (H/D) & 5.08 & 1.29 & 36 & & & & & & & & 0.024 \\
8. Wind (K/H) & 22.79 & 2.82 & 36 & & & & & & & & \\
\hline
\end{tabular}

**. Correlation is significant at the 0.01 level (2-tailed).

*. Correlation is significant at the 0.05 level (2-tailed).

Note. HKAD is Hong Kong resident departures number by air; GDP is Gross Domestic Product in Hong Kong; CPI is Consumer Price Index in Hong Kong; Cost is transportation costs in Hong Kong; Temp is rating for daily temperature in Hong Kong; Hum is rating for daily humidity in Hong Kong; Sun is rating for duration of sunshine in Hong Kong; Wind is rating for wind speed measured in kilometers per hour in Hong Kong.

Table 4. Descriptive statistics and correlations in Hong Kong resident departures by sea

\begin{tabular}{llllllllllll}
\hline Variables & Mean & Std. Deviation & $\mathrm{N}$ & 1 & 2 & 3 & 4 & 5 & 6 & 7 & 8 \\
\hline 1.HKSD (No.) & 2035815.94 & 148945.95 & 36 & 0.14 & -0.08 & 0.208 & $.349^{*}$ & -0.147 & $.553^{* *}$ & -0.29 \\
2. GDP (million HKD) & 439392.28 & 63381.15 & 36 & & $.916^{* *}$ & $.653^{* *}$ & 0.048 & $-0.400^{*}$ & $.352^{*}$ & .276 \\
3. CPI (\%) & 100.46 & 8.19 & 36 & & & $.644^{*}$ & -0.035 & -0.201 & 0.064 & .160 \\
4. Cost (USD/Barrel) & 80.26 & 19.61 & 36 & & & & 0.109 & -0.042 & 0.078 & -.078 \\
5. Temp ( $\left({ }^{\circ} \mathrm{C}\right)$ & 23.29 & 4.26 & 36 & & & & & & $.462^{* *}$ & $.447^{* *}$ & $-.576^{* *}$ \\
6. Hum (\%) & 77.85 & 5.19 & 36 & & & & & & & $-.485^{* *}$ & $-.688^{* *}$ \\
7. Sun (H/D) & 5.08 & 1.29 & 36 & & & & & & & & 0.024 \\
8. Wind (K/H) & 22.79 & 2.82 & 36 & & & & & & & & \\
\hline
\end{tabular}

**. Correlation is significant at the 0.01 level (2-tailed).

*. Correlation is significant at the 0.05 level (2-tailed).

Note. HKSD is Hong Kong resident departures number by sea; GDP is Gross Domestic Product in Hong Kong; CPI is Consumer Price Index in Hong Kong; Cost is Transportation costs in Hong Kong; Temp is Rating for daily temperature in Hong Kong; Hum is Rating for daily humidity in Hong Kong; Sun is Rating for duration of sunshine in Hong Kong; Wind is Rating for wind speed measured in kilometers per hour in Hong Kong; 
Table 5. Descriptive statistics and correlations in Hong Kong resident departures by land

\begin{tabular}{|c|c|c|c|c|c|c|c|c|c|c|c|}
\hline Variables & Mean & Std. Deviation & $\mathrm{N}$ & 1 & 2 & 3 & 4 & 5 & 6 & 7 & 8 \\
\hline 1.HKLD (No.) & 16613398.39 & 968175.64 & 36 & & $.762 * *$ & $.687 * *$ & $.562 * *$ & 0.197 & -0.283 & $.361 *$ & 0.055 \\
\hline 2. GDP (million HKD) & 439392.28 & 63381.15 & 36 & & & $.916^{* *}$ & $.653 * *$ & 0.048 & $-0.400 *$ & $.352 *$ & .276 \\
\hline 3. CPI (\%) & 100.46 & 8.19 & 36 & & & & $.644 *$ & -0.035 & -0.201 & 0.064 & .160 \\
\hline 4. Cost (USD/Barrel) & 80.26 & 19.61 & 36 & & & & & 0.109 & -0.042 & 0.078 & -.078 \\
\hline 5. Temp $\left({ }^{\circ} \mathrm{C}\right)$ & 23.29 & 4.26 & 36 & & & & & & $.462 * *$ & $.447 * *$ & $-.576 * *$ \\
\hline 6. Hum (\%) & 77.85 & 5.19 & 36 & & & & & & & $-.485 * *$ & $-.688 * *$ \\
\hline 7. Sun (H/D) & 5.08 & 1.29 & 36 & & & & & & & & 0.024 \\
\hline 8. Wind $(\mathrm{K} / \mathrm{H})$ & 22.79 & 2.82 & 36 & & & & & & & & \\
\hline
\end{tabular}

**. Correlation is significant at the 0.01 level (2-tailed).

*. Correlation is significant at the 0.05 level (2-tailed).

Note. HKLD is Hong Kong resident departures number by land; GDP is Gross Domestic Product in Hong Kong; CPI is Consumer Price Index in Hong Kong; Cost is transportation costs in Hong Kong; Temp is rating for daily temperature in Hong Kong; Hum is rating for daily humidity in Hong Kong; Sun is rating for duration of sunshine in Hong Kong; Wind is rating for wind speed measured in kilometers per hour in Hong Kong.

Table 6 shows the time series multiple regression result of the four regression models in this study. The growth of Hong Kong resident departures is positive significantly related to the levels of Consumer Price Index (CPI) and temperature (Temp). Furthermore, it is negative significantly related to humidity (Hum). The R-square for this model is 0.737 (with adjusted R-square 0.671 ). This suggests that the model can explain around $73.7 \%$ of the variation of the dependent variable. The growth of Hong Kong resident departures by Air is positive significantly related to the levels of Gross Domestics Product (GDP) and Transportation cost (Cost). The R-square for this model is 0.814 (with adjusted R-square 0.768 ). This suggests that the model can explain around $81.4 \%$ of the variation of the dependent variable. The growth of Hong Kong resident departures by Sea exhibits no significant relationship with the independent variables. The R-square for this model is 0.447 (with adjusted R-square 0.309). This suggests that the model can explain around $44.7 \%$ of the variation of the dependent variable. The growth of Hong Kong resident departures by Land is positive significantly related to the levels of Consumer Price Index (CPI) and temperature (Temp). Furthermore, it is negative significantly related to humidity (Hum). The R-square for this model is 0.696 (with adjusted R-square 0.62 ). This suggests that the model can explain around $69.6 \%$ of the variation of the dependent variable. Since the descriptive statistics show significant correlations among independent variables, the variance inflation factor (VIF) was computed for each independent variable to assess the impact of collinearity among the independent variables, which could potentially confound the analysis. Low VIF values indicate low interrelations among independent variables, and VIF values greater than 10 indicate high levels of multicollinearity (Neter et al., 1996). The VIF values associated with the independent variables reported in the regression analyses are all well below 7 , which suggest the collinearity problem is not serious to temper the data. As the dataset is time-series data, the Durbin-Watson statistic was computed to test for autocorrelation among residuals. The Durbin-Watson statistic ranges in value from 0 to 4 (Chatterjee \& Hadi, 2006). In the current study, the observed values for the models were in the acceptable range (D-W statistics less than 2)

Table 6. Time series multiple regression statistics in Hong Kong resident departures and mode of transport

\begin{tabular}{|c|c|c|c|c|c|c|c|c|}
\hline \multirow[t]{2}{*}{ Variables } & \multicolumn{2}{|c|}{ Hong Kong Resident Departures } & \multicolumn{2}{|l|}{ By Air } & \multicolumn{2}{|l|}{ By Sea } & \multicolumn{2}{|l|}{ By Land } \\
\hline & Coefficients & VIF & Coefficients & VIF & Coefficients & VIF & Coefficients & VIF \\
\hline GDP & 0.2 & 1.986 & $.642 * *$ & 1.99 & -0.143 & 1.986 & 0.051 & 1.986 \\
\hline CPI & $.431 * *$ & 1.722 & 0.109 & 1.72 & 0.116 & 1.722 & $.493 * *$ & 1.722 \\
\hline Cost & 0.2 & 1.758 & $.252 *$ & 1.76 & 0.133 & 1.758 & 0.228 & 1.758 \\
\hline Temp & $.398 *$ & 3.754 & 0.099 & 3.75 & -0.023 & 3.754 & $.483 *$ & 3.754 \\
\hline Hum & $-0.524 *$ & 6.848 & 0.218 & 6.85 & -0.252 & 6.848 & $-0.696^{*}$ & 6.848 \\
\hline Sun & -0 & 4.622 & 0.198 & 4.62 & 0.446 & 4.622 & -0.23 & 4.622 \\
\hline Wind & -0 & 2.648 & -0.067 & 2.65 & -0.442 & 2.648 & -0.148 & 2.648 \\
\hline R Square & 0.7 & & 0.814 & & 0.447 & & 0.696 & \\
\hline Adjusted R Square & 0.7 & & 0.768 & & 0.309 & & 0.62 & \\
\hline $\mathrm{F}$ & $11.82 * *$ & & $17.534^{* *}$ & & $3.231 *$ & & $9.155^{* *}$ & \\
\hline Durbin-Watson & 0.9 & & 1.019 & & 0.887 & & 0.94 & \\
\hline Number of obs & 36 & & 36 & & 36 & & 36 & \\
\hline
\end{tabular}


**. Correlation is significant at the 0.01 level (2-tailed).

*. Correlation is significant at the 0.05 level (2-tailed).

Note. HKRD is Hong Kong resident departures number; HKAD is Hong Kong resident departures number by air; HKSD is Hong Kong resident departures number by sea; HKLD is Hong Kong resident departures number by land; GDP is Gross Domestic Product in Hong Kong; CPI is Consumer Price Index in Hong Kong; Cost is transportation costs in Hong Kong; Temp is rating for daily temperature in Hong Kong; Hum is rating for daily humidity in Hong Kong; Sun is rating for duration of sunshine in Hong Kong; Wind is rating for wind speed measured in kilometers per hour in Hong Kong;

\section{Conclusions and Implications}

This study presents findings in estimating the impact of climate on the growth of Hong Kong resident's mode of transport in Hong Kong. The number of Hong Kong resident's mode of transport has a number of unique characteristics that accounts for climate change in Hong Kong.

First, the results present strong evidence on the influence of climate on Hong Kong resident's mode of transport. The Model 1 and Model 4 can explain a large percentage of the variation of Hong Kong resident departures. Positive relationships are found between resident departures and Consumer Price Index and temperature, while negative relationships are found for humidity. Furthermore, an insignificant relationship is found between Gross Domestics Product, Transportation cost, Duration of sunshine, Wind speed and the growth of Hong Kong resident departures. The most frequently used mode of transport for Hong Kong resident is by Land. Therefore, the two models, Model 1 and Model 4, exhibit similar results. CPI represents the tourism price in Hong Kong. When the tourism price in Hong Kong increases, people will substitute Hong Kong tourism products with foreign tourism products, hence the number of departures of Hong Kong residents increases. Furthermore, our results also confirmed when temperature increases, local departure increases (Wilton and Wirjanto, 1998). Alternatively, Humidity is negatively and significantly related to Hong Kong resident departures. Generally speaking, when Hong Kong people are departing from land, Mainland China is the only destination. During rainy days, humidity increases, the desire to travel would decrease; hence the number of departure decreases.

Second, Model 2 describes the pattern of Hong Kong resident departures by Air. The dependent variable is positively and significantly related to the GDP and transportation cost. GDP represents the disposable income, therefore, when GDP increases, the demand for long haul travel would increase and hence the number of departure increases. Transportation cost represents the cost of travel in Hong Kong. The result of this study shows that the transportation cost increase will improve the number of Hong Kong resident departures by Air.

Third, the Hong Kong resident departures by Sea (Model 3) are slightly different from the Hong Kong resident departures model (Model 1), Hong Kong resident departures by Air model (Model 2) and Hong Kong resident departures by Land model (Model 4). The interesting observation is that the all independent variables do not significantly relate to Hong Kong people departures. One possible explanation for this is that since the people travel by sea majority is to Macau. According to DSEC (2013), there are 6,766,044 Hong Kong residents visited Macau in 2013. Macau is a famous casino destination and some of Hong Kong residents seem is gamblers which have a particular travel pattern out of scope of this study, there are many forms of gambling and many types of gamblers, as there are differences in their characteristics and behaviors (Volberg and Moore, 1999).

This study makes two important contributions. First, this study enhances tourism literature by empirically testing that the effect of climate on the resident's mode of transport. Positive relationships are found in CPI and temperature in Hong Kong resident departures by Land, while an inconclusive relationship is found in GDP, Transportation cost, Humidity, Duration of sunshine, Wind speed. Humidity affects both overall and Hong Kong resident departures by Land negatively. Furthermore, GDP and Transportation cost affect Hong Kong resident departures by Air positively.

Second, for government or practitioners' perspective, this study provides a clearer understanding of climate impact on Hong Kong resident's mode of transport. The difference in results between the four models shows us, 1 . Given the contrast of variable sign between Hong Kong resident departures (Model 1) and Hong Kong resident departures by Land (Model 4), climate mainly affects Hong Kong resident departures growth via Hong Kong resident departures by Land growth; 2 . Since some of the measured variables of climate show a negative sign in Model 1 and Model 4, this suggests that climate does not affect different modes of transport uniformly. Therefore, policy makers, while assessing the effect of climate change to Hong Kong resident departures, they can develop more appropriate services and tourism products according to the climate change in Hong Kong. For example, if we expect the temperature will increase in the long run, the demand for departing by land would increase, therefore, the corresponding border facilities should be improved to accommodate these changes, such as the 
amount of highways, public transportation system and etc. Furthermore, the results provide source information for various types of transport operators to improve their service and market share.

\section{Limitations and Future Research}

This study has a number of limitations that deserves further investigation. First, it is based on secondary data derived from Hong Kong tourism statistics, since the data set is established based on the data availability with limited years, as well as data such as the number of modes of Hong Kong resident departures prior to 2005, and other factors affecting Hong Kong resident departures have not been included such as GDP per capita. Meanwhile, this study is based on Hong Kong's Control Points setting, it should be investigated the relationship with other countries or regions. Further research can include interviews from the perspectives of government officials and Hong Kong residents to understand the influence their mode of transport factors, Finally, the effect of climate change toward outbound tourism is not one-dimensional and have therefore come out with this research initiative to investigate those factors and identify the sign and magnitude of the effect these factors has on outbound tourism development. For example, urbanization should be a key factor influencing tourism development and climate change (Zhang, Luo, Xiao, \& Denizci, 2013; Luo, Qiu, \& Lam, 2015). Furthermore, the issue of environmental pollution and tourism sustainability as a result of climate change is alarming and it certainly should draw attentions from tourism researchers.

\section{References}

Amelung, B., Nicholls, S., \& Viner, D. (2007). Implications of global climate change for tourism flows and seasonality. Journal of Travel Research, 45(3), 285-296. http://dx.doi.org/10.1177/0047287506295937

Census and Statistic Department of Hong Kong. (2010). Public Transport Patronage of Hong Kong, 1999 to 2009. Retrieved May 2, 2014, from http://www.censtatd.gov.hk/hkstat/sub/sp130.jsp?productCode=FA100065

Census and Statistic Department of Hong Kong. (2005-2013). Hong Kong Statistics. Retrieved May 1, 2014, from http://www.censtatd.gov.hk/hkstat/sub/bbs.jsp

Chatterjee, S., \& Hadi, A. S. (2006). Regression Analysis by Example. Hoboken, NJ: Wiley and Sons. http://dx.doi.org/10.1002/0470055464

Chen, M. H. (2010). The economy, tourism growth and corporate performance in the Taiwanese hotel industry. Tourism Management, 31(5), 665-675. http://dx.doi.org/10.1016/j.tourman.2009.07.011

Cheung, C., \& Law, R. (2001). Determinants of tourism hotel expenditure in Hong Kong. International Journal of Contemporary Hospitality Management, 13(3), 151-158. http://dx.doi.org/10.1108/09596110110388945

Ching-chi, C. L., \& Si, C. L. W. (2010). Hotel Occupancy Rate in a Gambling Destination: A Longitudinal Study of the Macao Hotel Industry 2004-2007. Journal of Hospitality and Tourism Management, 17(01), 34-43. http://dx.doi.org/10.1375/jhtm.17.1.34

Climate Change Business Forum. (2013). How will Hong Kong be Affected by Climate Change? Retrieved September 2, 2013, from http://www.climatechangebusinessforum.com/en-us/hong_kong_context_affected

Eugenio-Martin, J. L., \& Campos-Soria, J. A. (2010). Climate in the region of origin and destination choice in outbound tourism demand. Tourism Management, 31(6), 744-753.

Goh, C. (2012). Exploring impact of climate on tourism demand. Annals of Tourism Research, 39(4), 1859-1883. http://dx.doi.org/10.1016/j.annals.2012.05.027

Goh, C., Law, R., \& Mok, H. M. (2008). Analyzing and forecasting tourism demand: A rough sets approach. Journal of Travel Research, 46(3), 327-338. http://dx.doi.org/10.1177/0047287506304047

Harvey, G. (1986). Study of airport access mode choice. Journal of transportation Engineering, 112(5), 525-545. http://dx.doi.org/10.1061/(ASCE)0733-947X(1986)112:5(525)

Hong Kong Observatory. (2013). Observed Climate Change in Hong Kong. Retrieved September 2, 2013, from http://www.weather.gov.hk/climate_change/obs_hk_temp_e.htm

Hong Kong Observatory. (2005-2013). Hong Kong Climatology. Retrieved March 1, 2014, from http://www.hko.gov.hk/wxinfo/currwx/current.htm.

Hong Kong Tourism Board. (HKTB). (2005-2013). A statistical review of Hong Kong tourism. Hong Kong: HKTB. 
Leung, Y. K., Wu, M. C., \& Yeung, K. H. (2006). Climate Forecasting - What the Temperature and Rainfall in Hong Kong are Going to be Like in 100 Years? Hong Kong Observatory, Reprint 638. Hong Kong Special Administrative Region Government.

Lise, W., \& Tol, R. S. (2002). Impact of climate on tourist demand. Climatic change, 55(4), 429-449. http://dx.doi.org/10.2139/ssrn.278516

Lyons, S., Mayor, K., \& Tol, R. S. (2009). Holiday destinations: Understanding the travel choices of Irish tourists. Tourism management, 30(5), 683-692. http://dx.doi.org/10.1016/j.tourman.2008.10.024

Luo, J.M., Qiu, H., \& Lam, C.F. (2015). Urbanization Impacts on Regional Tourism Development: a Case Study in China. Current Issues in Tourism. http://dx.doi.org/10.1080/13683500.2015.1033385.

Mieczkowski, Z. (1985). The tourism climatic index: a method of evaluating world climates for tourism. The Canadian Geographer/Le Géographe canadien, 220(3), 233. http://dx.doi.org/10.1111/j.1541-0064.1985.tb00365.x

Morley, C. L. (1994). The use of CPI for tourism prices in demand modelling. Tourism Management, 15(5), 342-346. http://dx.doi.org/10.1016/0261-5177(94)90088-4

Neter, J., Kutner, M. H., Nachtsheim, C. J., \& Wasserman, W. (1996). Applied Linear Statistical Models. Irwin, Chicago.

Statistics and Census Bureau (DSEC). (2013). Statistics Database. Retrieved December 20, 2013, from http://www.dsec.gov.mo/TimeSeriesDatabase.aspx?lang=en-US

Taylor, T., \& Ortiz, R. A. (2009). Impacts of climate change on domestic tourism in the UK: a panel data estimation. Tourism Economics, 15(4), 803-812. http://dx.doi.org/10.5367/000000009789955161

U.S. Energy Information Administration. (2005-2013). Spot Prices. Retrieved May 2, 2014, from http://www.eia.gov/dnav/pet/pet_pri_spt_s1_d.htm

United Nations World Tourism Organization (UNWTO). (2014). World Tourism Barometer. Retrieved May 2, 2014, from http://mkt.unwto.org/barometer/january-2014-volume-12

Volberg, R., \& Moore, W. L. (1999). Report to the Washington State Lottery on gambling and problem gambling in Washington State: A replication study, 1992 to 1998. Washington State Council on Problem Gambling, Olympia.

Wilton, D., \& Wirjanto, T. (1998). An analysis of the seasonal variation in the national tourism indicators. Canadian Tourism Commission, Ottawa, Canada.

Witt, S. F., \& Witt, C. A. (1995). Forecasting tourism demand: A review of empirical research. International journal of Forecasting, 11(3), 447-475. http://dx.doi.org/10.1016/0169-2070(95)00591-7

Zhang, H., Luo, J.M., Xiao, Q., \& Denizci Guillet, B. (2013). The Impact of Urbanization on Hotel Development: Evidence from Guangdong Province in China. International Journal of Hospitality Management, 34, 92-98. http://dx.doi.org/10.1016/j.ijhm.2013.02.013

Zhang, H. Q., Qu, H., \& Tang, V. M. Y. (2004). A case study of Hong Kong residents' outbound leisure travel. Tourism Management, 25(2), 267-273. http://dx.doi.org/10.1016/S0261-5177(03)00096-7

\section{Copyrights}

Copyright for this article is retained by the author(s), with first publication rights granted to the journal.

This is an open-access article distributed under the terms and conditions of the Creative Commons Attribution license (http://creativecommons.org/licenses/by/3.0/). 